\title{
Research of Key Impact Factors for Higher Agricultural Education Resources Management Based on the Grey Statistics
}

\author{
First Author:Li Zhang \\ line 1 (of Affiliation): Harbin University of Commerce \\ line 2: Harbin University of Commerce \\ line 3: Haerbin, China \\ line 4: zhangli007008@126.com \\ line 5:045184839484
}

\author{
Second Author*:Yanyan Li \\ line 1 (of Affiliation): Harbin University of Commerce \\ line 2: Harbin University of Commerce \\ line 3: Haerbin, China \\ line 4: 1053266214@qq.com \\ line 5:13836181044 \\ *Corresponding author
}

\begin{abstract}
After synthesizing the research results at home and abroad, we give the initial indicator set of impact factors of higher agricultural education resource management, and then on this basis we design and issue the questionnaire of expert group. Using the principle of grey statistics, We Calculated the importance degree of the questionnaire with data processing and grey statistics for whiten function,so as to determine the key factors of higher agricultural education resource management.
\end{abstract}

Keywords-grey statistics; higher education; agricultural education resources; impact factor

\section{INTRODUCTION}

Higher agricultural education as an important part of higher education in China, is a leading agricultural education, is a high-level agricultural talents cultivation, scientific research, technology promotion, industry development, the important base of technology innovation. Higher agricultural education in recent years, our country implements the reform and development of span, the development of social economy in our country, especially in the rural economy has played a role in promoting positive impact ${ }^{[1]}$. Under the condition of existing national condition, higher agricultural education resources as a special form of education resources, is the economic development of our country, especially the regional characteristic economy rapid and healthy development essential knowledge and technical support. However, the limited higher agricultural education resources and the rapid development of agricultural economy is still lack of effective configuration and management mechanism, between the higher agricultural education resource support cannot give full play to the effect of economic development, causing some effective waste of resources. Therefore, accelerate the establishment of higher agricultural education efficient allocation of resources and management mechanism, improve the structure of higher agricultural education resource adequately, play their own advantages, to effectively carry out the "twelfth five-year" development strategy, promote local economic steady and healthy development has important theoretical significance and practical significance.
From the micro perspective of resource management, this paper gives higher agricultural education resource management influence factor of the initial indicator set, using the principle of grey statistics initial key impact factor index in the collection, screening for higher agricultural education resource management eventually lay the ground to establish evaluation index system.

\section{HIGHER AGRICULTURAL EDUCATION RESOURCE MANAGEMENT INFLUENCE FACTOR OF THE INITIAL INDICATOR SET}

Internal and external environment of higher agricultural education development in our country, the comprehensive Chinese scholars on higher agricultural education in higher education and the previous research literature, this study collected and impact factors of higher agricultural education in China resources management initial index collection, such as table 1 "index" and "main factors" column.

The main factors that influence the initial indicator set a total of 38, they are all in different extent, reflects the impact of higher agricultural education resource management information. According to the initial indicator set design and issuing questionnaires of 90 expert group, a total of 77 effective questionnaires were taken back, on the recovery of information collection and sorting of the questionnaire for space reasons, the specific process go here.

\section{USING THE PRINCIPLE OF GREY STATISTICS FILTER METHOD AND PROCEDURE OF THE KEY FACTORS}

\section{A. Construct the Grey Whitening Weight Function}

According to relevant experts to higher agriculture education resource management factors affecting the degree of importance to three classes ${ }^{[11]}$ : hight, midium and low . Constructing various grades of grey whitening weight functions such as formula (1), (2), (3). Set $f_{k}(i j)$ is the first $j$ factors that affect the degree of importance for the first $i$ albino function, $K$ is the grey whitening weight function number, 
$K=1,2,3, \boldsymbol{d}_{i j}$ is the first $j$ factors affecting the degree of importance for the $i$ score, the calculating formula for $f_{k}(i j)$ is (1),(2),(3), $i=1,2, \cdots 7, j=1,2, \cdots 46$.

The first kind of "hight" , $K=1$, the grey whitening weight function is

$$
f_{1}(i j)=\left\{\begin{array}{cc}
1 & d_{i j} \geq 7 \\
\frac{d_{i j}-4}{7-4} & 4<d_{i j}<7 \\
0 & d_{i j} \leq 4
\end{array}\right.
$$

The second kind of "medium", $K=2$, the grey whitening weight function is

$$
f_{2}(i j)=\left\{\begin{array}{cc}
0 & d_{i j}<1 \\
\frac{d_{i j}-1}{4-1} & 1<d_{i j}<4 \\
1 & d_{i j}=4 \\
\frac{7-d_{i j}}{7-4} & 4<d_{i j}<7 \\
0 & d_{i j}>7
\end{array}\right.
$$

The third kind of "low" , $K=3$, the grey whitening weight function is

$$
f_{3}(i j)=\left\{\begin{array}{cc}
0 & d_{i j} \geq 4 \\
\frac{4-d_{i j}}{4-1} & 1<d_{i j}<4 \\
1 & d_{i j} \leq 1
\end{array}\right.
$$

\section{B. Calculating Grey Decision Coefficient}

The expert group for the main factors affecting the degree of importance for the score of statistics, summarised in table, then according to the gray statistical formula (4) to calculate decision coefficient $\eta_{k}(j)$ :

$$
\eta_{k}(j)=\sum n(i j) f_{k}(i j)
$$

Among them $: \eta_{k}(j)$ is the first $j$ factors belonging to the first $K$ grey decision coefficient of a class ;

$f_{k}(i j)$ is the first $j$ factors that affect the degree of importance for the albino function of the $i$;

$n(i j)$ is the first $j$ factors that affect the degree of importance for the $i$ number of experts.

\section{To Determine the Decision Vector}

The grey class decision vector of every influence factor consists of three decision coefficient $\left\{\eta_{3}(j), \eta_{2}(j), \eta_{1}(j)\right\}$ of gray classes after calculation of formula (4), namely $\left\{\eta_{\text {low }}\right.$, $\left.\eta_{\text {midium }}, \eta_{\text {high }}\right\}$, all survey data through sorting and statistical method, grey decision vector and the relevant data such as shown in table 1. From the decision vector and importance can be seen in table 1, the influence factors of expert group for the importance degree of most focus on "high" and " midium", it shows that the main factors that influence the questionnaire designed by set, integrated from the reference literature and actual investigation, has the certain representativeness, and not to be an expert group for influence factors tend to overestimate.

\section{SELECTION OF THE KEY FACTORS}

We consider the importance and acquired two aspects, only selected important degree of the influence factors of "higher" class, considering some factors of the low availability is not operable, therefore, in the "high class" the influencing factors of the influence factors of easy access to less than $60 \%$, " $\sqrt{ }$ "said fnfluence actors," $x$ " said eliminating influence factors. Through the operation, We Screened out 26 key influence factor (table 1)

Through statistical analysis of gray and accessibility screening finalized 26 specific indicators that affect the basic management evaluation system of higher agricultural education resources eventually established.

\section{Higher Agricultural Education Resource MANAGEMENT KEY FACTOR IN THE SELECTION OF EXPERTS TEND TO ANALYZE}

\section{A. Comprehensiveness and Level Combining}

The results showed that all five level indicators are retained, and two indicators of distribution is relatively balanced, each one containing 5-6 two indicators index, covering teaching, research, management, input and output as well as higher basic information, such as the index system of agricultural education at all levels of both overall, and structured. Each level consists of a set of indicators form, are independent of each index, and contact each other and jointly form an organic whole, a complete evaluation system, avoiding repeated evaluation of index calculation.

\section{B. Qualitative and Quantitative Indicators Index Combines}

There are qualitative indicators in the initial set of seven indicators, 31 quantitative indicators. Excluding the 12 factors, there are 10 quantitative indicators, just delete the two qualitative indicators, but not because the index delete unimportant, but it is difficult to evaluate objectively. This shows that selecting the relevant staff and experts are more objective. In addition, due to the statistical differences in some quantitative indicators, but also led to a tendency to select expert qualitative indicators. Such selection results for the study of higher agricultural education resources will be more practical, but also validates our research.

\section{Combining Scientific and Operational}

The results show that, excluding the impact of 12 factors, accounting for $32 \%$ of all the factors. Fully reflects the relevant staff and experts on the scientific evaluation and operability of comprehensive consideration, try to make the whole evaluation system with minimal indicators cover the most amount of information so that the evaluation process has strong operability. 
TABLE I. IMPORTANCE INFLUENCING FACTORS DEGREE OF GREY STATISTICAL ANALYSIS AND AVAILABILITY OF COMPREHENSIVE SCREENING

\begin{tabular}{|c|c|c|c|c|c|c|c|}
\hline \multirow{2}{*}{ index } & \multirow{2}{*}{ Main influencing factors } & \multicolumn{3}{|c|}{ Decision vectors } & \multirow{2}{*}{$\begin{array}{l}\text { degree } \\
\text { of imp- } \\
\text { ortance }\end{array}$} & \multirow{2}{*}{$\begin{array}{c}\text { availability } \\
(\%)\end{array}$} & \multirow{2}{*}{$\begin{array}{l}\text { Whether } \\
\text { to choose }\end{array}$} \\
\hline & & $\eta_{\mathrm{L}}$ & $\eta_{\mathrm{м}}$ & $\eta_{\text {н }}$ & & & \\
\hline \multirow{8}{*}{$\begin{array}{l}\text { A } \\
\text { human } \\
\text { resources }\end{array}$} & $\begin{array}{l}\text { A1The number of teaching and } \\
\text { research staff }\end{array}$ & 1.83 & 10.02 & 65.15 & $\mathrm{H}$ & 95.67 & $\sqrt{ }$ \\
\hline & $\begin{array}{l}\text { A2The proportion of teaching and } \\
\text { research staff of total higher education } \\
\text { teaching and research staff }\end{array}$ & 4.60 & 15.17 & 57.23 & $\mathrm{H}$ & 94.39 & $\sqrt{ }$ \\
\hline & A3The number of management staff & 15.10 & 45.22 & 16.68 & M & 98.32 & $x$ \\
\hline & $\begin{array}{l}\text { A4The proportion of management } \\
\text { staff of total higher education of } \\
\text { management staff }\end{array}$ & 14.8 & 47.31 & 14.89 & M & 97.28 & $x$ \\
\hline & $\begin{array}{l}\text { A5The number of master's degree in } \\
\text { teaching and research staff over }\end{array}$ & 6.37 & 9.80 & 60.83 & $\mathrm{H}$ & 98.15 & $\sqrt{ }$ \\
\hline & A6The number of overseas students & 0.56 & 19.21 & 58.35 & $\mathrm{H}$ & 93.17 & $\sqrt{ }$ \\
\hline & $\begin{array}{l}\text { A7The number of external research } \\
\text { staff }\end{array}$ & 5.81 & 17.49 & 53.70 & $\mathrm{H}$ & 89.63 & $\sqrt{ }$ \\
\hline & $\begin{array}{l}\text { A8Teacher qualification examin- } \\
\text { ation pass rate }\end{array}$ & 13.00 & 40.22 & 23.78 & M & 98.91 & $\times$ \\
\hline \multirow{9}{*}{$\begin{array}{l}\quad \text { B } \\
\text { input of } \\
\text { funds }\end{array}$} & B1The total annual investment funds & 8.23 & 39.98 & 28.79 & M & 98.22 & $x$ \\
\hline & $\begin{array}{l}\text { B2The total investment per capita } \\
\text { expenditure }\end{array}$ & 4.47 & 23.18 & 49.35 & $\mathrm{H}$ & 92.87 & $\sqrt{ }$ \\
\hline & B3Annual research funding & 16.10 & 41.59 & 19.31 & M & 89.13 & $\times$ \\
\hline & B4Per capita research funding & 16.43 & 21.20 & 39.37 & $\mathrm{H}$ & 87.25 & $\sqrt{ }$ \\
\hline & B5Annual education funding & 11.83 & $\begin{array}{l}45.3 \\
7 \\
\end{array}$ & 19.80 & M & 85.16 & $\times$ \\
\hline & B6Per capita education funding & 3.30 & 29.11 & 44.59 & $\mathrm{H}$ & 86.28 & $\sqrt{ }$ \\
\hline & B7Annual infrastructure funding & 17.20 & 39.77 & 20.03 & $\mathrm{M}$ & 88.19 & $\times$ \\
\hline & B8Per capita infrastructure funding & 4.02 & 25.88 & 47.10 & $\mathrm{H}$ & 87.11 & $\sqrt{ }$ \\
\hline & $\begin{array}{l}\text { B9The total investment expenditure to } \\
\text { GDP ratio }\end{array}$ & 0.29 & 21.21 & 55.08 & $\mathrm{H}$ & 90.21 & $\sqrt{ }$ \\
\hline \multirow{7}{*}{$\begin{array}{l}\mathrm{C} \\
\text { Infrastruct } \\
\text { ure }\end{array}$} & $\begin{array}{l}\text { C1The size of the number of people over } \\
\text { the University }\end{array}$ & 4.61 & 32.61 & 49.00 & $\mathrm{H}$ & 99.03 & $\sqrt{ }$ \\
\hline & $\begin{array}{l}\text { C2The total number of educational } \\
\text { institutions }\end{array}$ & 6.31 & 44.39 & 26.30 & M & 89.47 & $\times$ \\
\hline & $\begin{array}{l}\text { C3The total proportion of educational } \\
\text { institutions of higher education } \\
\text { institutions }\end{array}$ & 6.37 & 33.19 & 37.44 & $\mathrm{H}$ & 83.54 & $\sqrt{ }$ \\
\hline & C4Network construction & 2.74 & 17.23 & 57.03 & $\mathrm{H}$ & 72.51 & $\sqrt{ }$ \\
\hline & C5Multimedia classrooms ownership & 11.63 & 22.10 & 43.27 & $\mathrm{H}$ & 85.13 & $\sqrt{ }$ \\
\hline & C6Fixed assets & 9.27 & 26.48 & 41.25 & $\mathrm{H}$ & 83.25 & $\sqrt{ }$ \\
\hline & C7Gross intangible assets & 11.50 & 25.72 & 39.78 & $\mathrm{H}$ & 67.45 & $\sqrt{ }$ \\
\hline \multirow{7}{*}{$\begin{array}{l}\quad \text { D } \\
\text { Managem } \\
\text { ent of } \\
\text { environm } \\
\text { ent }\end{array}$} & D1Office administrative efficiency & 3.97 & 23.90 & 49.13 & $\mathrm{H}$ & 53.31 & $\times$ \\
\hline & $\begin{array}{l}\text { D2Development of relevant policies } \\
\text { and regulations }\end{array}$ & 4.42 & 26.07 & 43.51 & $\mathrm{H}$ & 68.83 & $\sqrt{ }$ \\
\hline & D3Constraints and incentive systems & 2.03 & 29.68 & 45.29 & $\mathrm{H}$ & 75.67 & $\sqrt{ }$ \\
\hline & $\begin{array}{l}\text { D4The proportion of professional and } \\
\text { managerial staff }\end{array}$ & 6.80 & 30.70 & 39.50 & $\mathrm{H}$ & 70.28 & $\sqrt{ }$ \\
\hline & $\begin{array}{l}\text { D5Management decision-making } \\
\text { capacity }\end{array}$ & 12.23 & 23.30 & 41.47 & $\mathrm{H}$ & 52.39 & $\times$ \\
\hline & $\begin{array}{l}\text { D6Relevant administrative } \\
\text { departments }\end{array}$ & 5.84 & 26.37 & 44.79 & $\mathrm{H}$ & 77.88 & $\sqrt{ }$ \\
\hline & D7Publicity and training situation & 3.07 & 26.22 & 47.71 & $\mathrm{H}$ & 75.33 & $\sqrt{ }$ \\
\hline \multirow{3}{*}{$\begin{array}{c}\text { E } \\
\text { Produce } \\
\text { of }\end{array}$} & E1University enrollments & 9.77 & 17.40 & 49.83 & $\mathrm{H}$ & 91.20 & $\sqrt{ }$ \\
\hline & E2Degree completion rates & 10.57 & 40.23 & 26.10 & $\mathrm{M}$ & 93.07 & $\times$ \\
\hline & E3Graduate employment rate & 8.09 & 20.39 & 48.52 & $\mathrm{H}$ & 97.82 & $\sqrt{ }$ \\
\hline
\end{tabular}




\begin{tabular}{|c|c|c|c|c|c|c|c|}
\hline \multirow{4}{*}{$\begin{array}{l}\text { teaching } \\
\text { and } \\
\text { research }\end{array}$} & $\begin{array}{l}\text { E4The average annual number of } \\
\text { master's degrees awarded }\end{array}$ & 1.89 & 27.30 & 47.81 & $\mathrm{H}$ & 98.99 & $\sqrt{ }$ \\
\hline & $\begin{array}{l}\text { E5Annual provincial level or above } \\
\text { the absolute number of research } \\
\text { projects }\end{array}$ & 14.30 & 21.35 & 41.35 & $\mathrm{H}$ & 97.36 & $\sqrt{ }$ \\
\hline & $\begin{array}{l}\text { E6Annual research volume book } \\
\text { publishing }\end{array}$ & 4.29 & 39.30 & 33.41 & $\mathrm{M}$ & 92.11 & $x$ \\
\hline & $\begin{array}{l}\text { E7The average annual number of } \\
\text { teaching and research achievement } \\
\text { award }\end{array}$ & 8.48 & 23.80 & 44.72 & $\mathrm{H}$ & 93.45 & $\sqrt{ }$ \\
\hline
\end{tabular}

\section{CONCLUSION}

In the process of recovery and expert advisory questionnaire, we found that researchers and workers in urgent need of a scientific evaluation system, a reasonable higher agricultural education resources in order to better grasp the guidance of higher agricultural education resources related to management. Currently, very few domestic research literature related to higher agricultural education resource management factors, higher agricultural education is a difficult factor affecting resource management research. In view of this, the paper on the basis of domestic literature reference, combined with expert consultation questionnaire and repeated surveys, collection and became "Higher Agricultural Education Resource Management key factor in the initial set of indicators," come to have an important impact indicators of 26 . Factors collection and screening indicators scientific, rational and represent the views of the majority of industry experts and peers, with a strong operational. It should be noted that the key factors influencing the screening results are not the same level, with the continuous development of higher agricultural education and improvement and constant attention of government departments, the need to constantly add new factors have a significant impact, so in order to make a more comprehensive evaluation reasonable.

\section{REFERENCES}

[1] Schwartzman,S. March 2004."Equity, quality and relevance in higher education in Brazil,"Anais da Academia Brasileira de Ciencias.v 76, n 1, pp.173-88
[2] St,George,E.Positioning higher education for the knowledge based economy.Higher Education.v 52, n 4, pp.589-610, Dec. 2006.

[3] Durden,G.R.Yang,G.Higher vocational education in China: A preliminary critical review of developments and issues in Liaoning province.Journal of European Industrial Training.v 30, n 8, pp.622-38, 2006.

[4] Psarras,John E.Education and training in the knowledge-based economy: The application of knowledge management.International Journal of Information Technology and Management.v 6, n 1, pp.92-104, 2007.

[5] Rassmussen,Jesper;Kaltoft,Pernille.Alternative versus conventional attitudes in higher agricultural education.Alternative Agriculture \& Horticulture.20 (4), pp. 347-363, 2003.

[6] C.J.Pearson;R.L.Ison.University education for multiple-goal agriculture in Australia.Agricultural Systems.v 38, n 4, pp.341-362, 1992.

[7] Herdon Miklos ;Varallyai Laszlo.Multidisciplinary aspects of learning information technology in accredited agricultural education programs.7th World Congress on Computers in Agriculture and Natural Resources 2009. pp. 98-104, 2009.

[8] Sookhtanlo.M;Mohammadi.H.M;Rezvanfar.A.Library informationseeking behaviour among undergraduate students of agricultural extension and education in Iran.Journal of Library \& Information Technology.v 29, n 4, pp.12-20, July. 2009.

[9] Abu-Hamdeh, Nidal H, Khdair, Adnan I. Higher education in agricultural mechanization in Jordan.Agricultural Mechanization in Asia, Africa and Latin America.v 31, n 1, pp. 59-62,2000.

[10] Department of Extension Education, CCS Haryana Agricultural University.Considerations of Farm Graduates for Choice of Specialization in Higher Agricultural Education.Environment and Ecology .v 26, n 4c, pp.34-41, July. 2008.

[11] Amiri,Z.R. Khandelwakl,P. Sahebjamnia,N.Enhancement of education in farm and food industry with adoption of computer-based information systems.Journal of Applied Sciences.v 8, n 22, pp.4220-4315 Nov. 2008. 